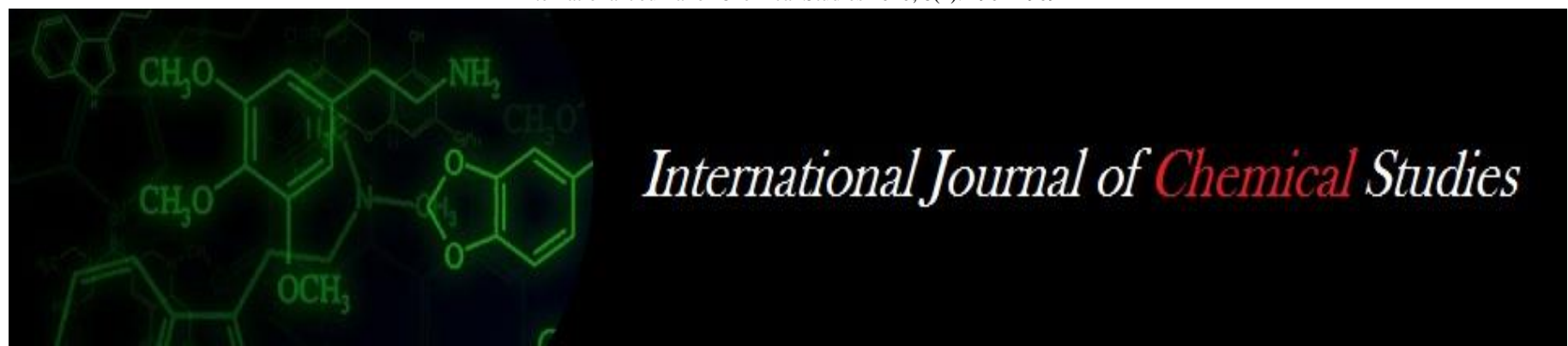

P-ISSN: 2349-8528

E-ISSN: 2321-4902

www.chemijournal.com

IJCS 2020; 8(4): 1904-1909

(C) 2020 IJCS

Received: 10-05-2020

Accepted: 12-06-2020

\section{NK Panda}

Department of Silviculture \&

Agroforestry, College of

Forestry, Odisha University of

Agriculture \& Technology,

Bhubaneswar, Odisha, India

\section{SK Sarangi}

Project Director, Shristi NGO,

Keonjhar, Odisha, India

SN Subudhi

M.Sc. (Forestry), College of

Forestry, OUAT, Bhubaneswar, Odisha, India

HK Das

M.Sc. (Forestry), College of Forestry, OUAT, Bhubaneswar, Odisha, India

Corresponding Author:

\section{NK Panda}

Department of Silviculture \&

Agroforestry, College of

Forestry, Odisha University of

Agriculture \& Technology,

Bhubaneswar, Odisha, India

\section{Potentials of coconut (Cocos nucifera) based agroforestry system in soil quality management in coastal Odisha}

\author{
NK Panda, SK Sarangi, SN Subudhi and HK Das
}

DOI: https://doi.org/10.22271/chemi.2020.v8.i4t.9907

\begin{abstract}
This paper presents a study carried out in Puri district of Odisha during June 2015 - May 2016 to determine the soil quality in coconut based agroforestry system in 15 different sizes ( 0.1 to 1.5 acre) of land holdings. The chosen coconut based agroforestry systems were visited in three cropping seasons such as kharif, rabi and summer and the observations on floral composition, height of plants, number of trees, number of livestock animals and birds, number of common plant species, different seasonal crops were recorded. The soil chemical analysis were carried out to assess the organic carbon, $\mathrm{N}, \mathrm{P}$ and $\mathrm{K}$ content along with the $\mathrm{pH}$ range. There are four different strata in which different perennial species were associated with coconut. The coconut based agroforestry systems of various sizes are playing important role for the household and the soil quality management which include productive role, protective and ameliorative role, recreational and educational role as well as developmental role giving various kinds of tangible and intangible benefits. The coconut based agroforestry system of size 0.8 acre was found to be best among the holding sizes studied with regard to various functions including soil health management in coastal Odisha.
\end{abstract}

Keywords: Coconut, agroforestry, nitrogen, phosphorus, $\mathrm{pH}$ range, organic carbon, role, Odisha

\section{Introduction}

In the arena of climate change, agriculture continues to struggle to meet the burgeoning food demandwhile sustainably managing the threats of soil erosion, land degradation and so on. The declaration of 2015 as 'International year of soils' by UN general assembly has certainly emphasized importance of soils in sustainable food systems. The need of the hour is to identify and promote land based systems and practices that maintains and improves soil resources which is crucial to our wellbeing. Among the various land use options today we have, agroforestry, which focuses on integration of trees in land use systems particularly Nitrogen fixing trees or multipurpose tree species in a view to increase the organic matter content and improving fertility status of soil, merits adequate attention. Coconut (Cocos nucifera) plays a significant role in the agrarian economy of India. Coconut is grown in more than 93 countries of the world in an area of 12.29 million ha with a total production in terms of copra equivalent of 11.04 million MT. Indonesia (25.63\%), Philippines $(23.91 \%)$ and India $(19.20 \%)$ are the major coconut producing countries of the world. Coconut based agroforestry means agriculture along with woody component with coconut plant as a compulsory. In India the coconut based agroforestry are generally found in tropical and sub-tropical areas and characterized by high species diversity and usually three to four vertical canopy strata. These agroforestry systems consist of different layer of species starting from seasonal crops, perennial crops, woddy components. The lower most being dominated by different vegetables like brinjal, greens, turmeric, ginger, mushroom, okra, chilli, tomato, cabbage, dioscorea, etc. and the second layer is comprising food plants such as banana, papaya, lemon, etc. The third layer is occupied by fruit trees like guava, drumstick, custard apple, etc. The upper layer is the tree layer which can be divided into two, consisting of the emergent full grown timber and fruit trees having height more than $20 \mathrm{~m}$ and medium size trees of $10-20 \mathrm{~m}$. In the upper layer species like Mangifera indica, Samanea saman, Bambusa vulgaris, B. tulda, Cocos nucifera, Areca catechu, Samania saman, Artocarpus heterophyllus, Aegle mormalus, Tamarindus indica, Azadirachta indica, 
Leucaena leucocephala, etc. are grown. In developing countries particularly in India coconut is either grown as mono-crop or as major component in the multiple cropping systems with or without livestock. In Odisha it occupies more than $60 \%$ of the perennial crop area and more than $30 \%$ of the total cropped area in costal districts mostly Puri, Jagtsingpur, Balasore, Kendrapada and Khurda. Mostly due to water logged situation and favour in climatic condition add interest on coconut plantation. Apart from pure coconut plantation many farmers and the households are practicing different crop combination along with coconut. The coconut farming system is very promising as spacing is wide, the system affords higher incidence of light under the canopy and the limited effective root zone of the coconuts allows other crops within the grove. Especially in the costal part of the district, vast lowland and homestead land areas are being planted with coconut. The advent of population pressure, less lands to cultivate and the worsening marginal conditions of farmlands prompt the need to go into farming systems that would optimize use of the limited land resource, thus intercropping, a form of agroforestry gained popularity among farmers. Basing on this background, an attempt was taken to assess the various role played and soil quality management by coconut based agroforestry system in coastal Odisha.

\section{Materials and Methods}

The present study was carried out in the Puri district of Odisha, a coastal district along the Bay of Bengal during June 2015 - May 2016. The experiment was laid out in Randomised Block Design (RBD) with three replications. For this the district was divided into three regions, each region represented one replication. The region-I covered the eastern part of the Puri district comprising four blocks such as Gop, Kaktpur, Astaranga and Puri. The region-II covered North central part of the district comprising Pipili, Delanga, Satyabadi and Kanasa blocks. The region-III covered the western part of the district comprising Chilika, Krushnaprasad and Brahmagiri blocks. In each region, the potentials of coconut based agroforestry in soil quality management of 15 different sizes were studied. The observations were recorded on floral composition, number of common plant species, height of plants growing in different strata, number of trees and number of livestock animals and birds in coconut based agroforestry system. For soil chemical analysis composite samples were collected from $0-30 \mathrm{~cm}$ depth in the month of June, 2015. The samples were collected from coconut based home gardens as well as adjoining open areas. After collection the samples were air dried under shade, finely ground and passed through a $2 \mathrm{~mm}$ sieve and finally $250 \mathrm{~g}$ of such soil were taken from each treatment plots in polythene bag with proper label for analysis of $\mathrm{pH}$, organic carbon, available nitrogen, phosphorus and potash by using glass electrode $\mathrm{p}^{\mathrm{H}}$ meter, Walkley and Black's rapid titration method, Subbiah and Asija (1956) method, Bray's-I method and Jackson, 1973 method respectively.

\section{Results and Discussion}

\subsection{Common perennial species in different strata of coconut based agroforestry system}

The common perennial plants were observed in four different strata under the coconut based agroforestry systems studied in fifteen different land holding sizes in Puri district of Odisha. The strata are more than $15 \mathrm{~m}, 10-15 \mathrm{~m}, 5-10 \mathrm{~m}$ and less than $5 \mathrm{~m}$. In all holding size coconut occupied the top most storey $(>15 \mathrm{~m})$. Between the holding size of $\mathrm{T}_{3}$ and $\mathrm{T}_{10}$ the common tree species associated in these strata were siris, rain trees, eucalyptus and karanj. No perennial plant was found with coconut in the holding size of 1.1acre and above. In very small holding size like $T_{1}$ and $T_{2}$ the presence of other trees were zero or negligible because of not availability of space. In relatively higher holding size $\left(T_{12}\right.$ to $\left.T_{15}\right)$ no other trees were associated because in such holdings sizes paddy is grown which needs more access to light. The common perennial plants were arecanut, mango and bamboo up to 1.2acre size holding in the strata of $10-15 \mathrm{~m}$ height. In relatively higher size holding within this limit $\left(\mathrm{T}_{3}\right.$ to $\left.\mathrm{T}_{12}\right)$ additional species like acacia, teak and jackfruit are grown. No perennial trees are found in the holding size $\mathrm{T}_{13}$ to $\mathrm{T}_{15}$ other than coconut in these strata. People grow these perennial trees along with coconut depending upon holding size to meet various requirements like food, fodder, fuel, timber etc. in addition to get a congenial microclimate and generate additional money and employment on the same land holding. In the strata 5$10 \mathrm{~m}$ height mostly crops were in different holding sizes of coconut based agroforestry system. Drumstick, papaya and guava are found commonly in small size holding like $\mathrm{T}_{1}$ and $T_{2}$. In relation to higher holdings size like $T_{3}$ to $T_{12}$ the common perennial plants were guava, papaya, pomegranate, drumstick and bael. People have grown these plants in different sizes of holding primarily to supplement the food from these plants. The wider spacing of coconut favors growing these fruit plants under it. In the strata of less than $5 \mathrm{~m}$ height the common plants are citrus, banana and curry leaf from $T_{1}$ to $T_{12}$ holding size. People are deliberately kept these plants to get food and leaf from these plants which are frequently required in household of rural people. In holding size 1.3 acre to 1.5 acre no associated perennial plants were found associated with coconut in any strata. This is because the higher size holding are mostly used for coconut paddy cropping system in the district. Different plants have occupied in different strata may be due their growth rate, light requirement and deliberate arrangement by the grower to intensify the coconut based land use system and explore maximum benefit. Similar study have been reported by Rahaman et al., (2013) ${ }^{[19]}$, Nair, (2008) ${ }^{[17]}$ and Fernades et al., (1984) ${ }^{[8]}$.

\subsection{Number of perennial plant in coconut based agroforestry}

The number of common perennial plant species including coconut, timber species and fruit species other than coconut varied remarkably in the coconut based agroforestry system of Puri district (Table 1). The number of coconut trees per holding varied from 25 to 118 with an increasing number towards higher size units. The number of coconut trees increased with increase of size of unit because of availability of more space to accommodate the trees on the other hand the number of coconut trees on acre basis ranged from 79 to 230 with a decreasing trend towards higher size plot. This indicates that the density of coconut trees is significantly higher in smaller size unit than the larger size unit. However the values beyond 0.8 acre were statistically at par with each other. This signifies that towards higher holding sizes the spacing of coconut trees maintained is more or less same. The number of timber species varied from 0 to 6 per holding. In holding size of 1.3 acre to 1.5 acre less number of timber species was found to be grown with coconut. This means towards higher holding sizes people prefer less mixture of perennial plants. In terms of number of timber species per acre basis significantly higher number of plants was found in 
relatively smaller size of plot. On others the number of timber species in coconut based agroforestry system decreased with increase of holding size. It varied from 0 to 27 numbers per acre. This reflects that the smaller size plots are comparatively denser because of more number of trees per unit area than the higher size plots. In higher size plot like $\mathrm{T}_{13}, \mathrm{~T}_{14}$ and $\mathrm{T}_{15}$ no other trees are present.

Table 1: Number of common perennial plant species in coconut based agroforestry system in Puri district of Odisha

\begin{tabular}{|c|c|c|c|c|c|c|}
\hline & \multicolumn{2}{|c|}{ Coconut tree } & \multicolumn{2}{|c|}{ Timber species } & \multicolumn{2}{|c|}{ Fruit species other than coconut } \\
\hline Treatment (Holding size) & Per holding & Per acre & Per holding & Per acre & Per holding & Per acre \\
\hline $\mathrm{T}_{1}(0.1$ acre $)$ & 25 & 230 & 3 & 27 & 3 & 33 \\
\hline $\mathrm{T}_{2}(0.2$ acre $)$ & 38 & 188 & 3 & 15 & 4 & 20 \\
\hline $\mathrm{T}_{3}(0.3$ acre $)$ & 50 & 166 & 4 & 12 & 4 & 12 \\
\hline $\mathrm{T}_{4}(0.4$ acre $)$ & 59 & 147 & 5 & 12 & 4 & 10 \\
\hline $\mathrm{T}_{5}(0.5$ acre $)$ & 63 & 126 & 5 & 9 & 5 & 10 \\
\hline $\mathrm{T}_{6}(0.6$ acre $)$ & 65 & 109 & 5 & 8 & 5 & 8 \\
\hline $\mathrm{T}_{7}(0.7$ acre $)$ & 66 & 95 & 6 & 8 & 5 & 7 \\
\hline $\mathrm{T}_{8}(0.8$ acre $)$ & 66 & 82 & 6 & 8 & 7 & 9 \\
\hline $\mathrm{T}_{9}(0.9$ acre $)$ & 68 & 76 & 4 & 4 & 3 & 3 \\
\hline $\mathrm{T}_{10}(1.0$ acre $)$ & 72 & 72 & 4 & 4 & 3 & 3 \\
\hline $\mathrm{T}_{11}(1.1$ acre $)$ & 85 & 77 & 3 & 2 & 2 & 2 \\
\hline $\mathrm{T}_{12}(1.2$ acre $)$ & 92 & 77 & 3 & 2 & 0 & 0 \\
\hline $\mathrm{T}_{13}(1.3$ acre $)$ & 100 & 77 & 0 & 0 & 0 & 0 \\
\hline $\mathrm{T}_{14}(1.4$ acre $)$ & 110 & 78 & 0 & 0 & 0 & 0 \\
\hline $\mathrm{T}_{15}(1.5$ acre $)$ & 118 & 79 & 0 & 0 & 0 & 0 \\
\hline $\mathrm{SE}_{\mathrm{m}( \pm)}$ & 1.68 & 4.66 & 0.31 & 1.26 & 0.22 & 1.17 \\
\hline $\mathrm{CD}_{(0.05)}$ & 4.89 & 13.51 & 0.92 & 3.67 & 0.65 & 3.38 \\
\hline
\end{tabular}

The number of fruit species other than coconut also found differently per holding in different size of unit. 2 to 7 number of fruit species were found per holding from 0.1 acre to 1.1acre and no fruit trees were found under coconut based agroforestry system. With regards to number of fruit species per acre the number was significantly higher in smaller size holding than the larger size holding. It ranged from 0 to 33 . Like coconut trees and timber species the fruit species were found more per unit area in comparatively small size plot. This shows that people tried to accommodate different type of trees which are essential to met different kinds of produces in their plot even if the size at the plot is small. The results are in line with findings of Jhon and Nair, (2002) ${ }^{[11]}$, Ahmed and Rahaman, (2004) ${ }^{[2]}$ and Ahmad et al., (2004) ${ }^{[3]}$.

\subsection{Common annual and seasonal crops in coconut based agroforestry system}

A number of common annual and seasonal crops were found to be grown in coconut based agroforestry in Puri district of Odisha (Table 2). In very small size holdings like 0.1 acre and 0.2 acre common annual crops were yam and turmeric. In holding size of 0.3 acre to 1.2 acre the common annual crops are papaya, yam, arrowroot and ginger. More number of annual crops was grown in relatively higher size holdings because of more availability of space as well as light on the ground. These annual crops are generally suitable to be grown under partial shade of tree canopy. Manjunath et al., (1998) ${ }^{[13]}$, Isaac and Nair, (2000) ${ }^{[9]}$ and Maheswarappa et al., (2000)
${ }^{[12]}$ have reported similar findings. However in comparatively large plots like 1.3acre and more no annual crops were found because in such plots paddy was only grown with coconut. With regards to common seasonal crops all holding sizes exerted crops in all the three season such as kharif, rabi and summer along with coconut trees. In kharif the common seasonal were brinjal, okra, bitter gourd, chilli and greens in holding size of 0.1 acre to 1.2 acre with additional crop of cowpea in relatively higher size plot. Beyond 1.2acre paddy was mostly grown in kharif with coconut. In rabi the common crops grown were tomato, brinjal and beans up to 0.3 acre size where as additional crops like cauliflower, onion and greens were found in relatively higher size holding up to 1.2acre. Beyond 1.2acre no rabi crops were grown under coconut. In summer the common crops were brinjal, chilli, beans up to 0.3 acre and additional crop of pumpkin in higher size plots. No seasonal crops was found to be grown beyond 1.2acre in summer. It was observed that crop diversity is more up to 1.2acre size holdings because these holdings were mostly the homesteads and available of water source where people grow the food crops essential for them and mostly managed by the family labour. On the other hand relatively higher holding size which were more than 1.2acre are paddy is grown in kharif and the coconut trees are located in the bunds of paddy field. Raising of different seasonal crops has also been reported by Nair (1986) ${ }^{[18]}$, Manjunath et al., (1998) ${ }^{[13]}$ and Isacc and Nair, (2000) ${ }^{[9]}$. 
Table 2: Common annual and seasonal crops in different coconut based agroforestry system in Puri district of Odisha

\begin{tabular}{|c|c|c|c|c|}
\hline \multirow{2}{*}{$\begin{array}{c}\text { Treatment } \\
\text { (Holding size) }\end{array}$} & \multirow{2}{*}{ Common Annual crops } & \multicolumn{3}{|c|}{ Common Seasonal crops } \\
\hline & & Kharif & Rabi & Summer \\
\hline $\mathrm{T}_{1}(0.1$ acre $)$ & Yam, Turmeric & Brinjal, Okra, Bitter gourd, Chilli, Greens & Tomato, Brinjal, Beans & Brinjal, Chilli, Greens \\
\hline $\mathrm{T}_{2}(0.2$ acre $)$ & Yam, Turmeric, Arrowroot & Brinjal, Okra, Bitter gourd, Chilli, Greens & Tomato, Brinjal, Beans & Brinjal, Chilli, Greens \\
\hline $\mathrm{T}_{3}(0.3$ acre $)$ & $\begin{array}{c}\text { Pine apple, Yam, Arrowroot, } \\
\text { Turmeric, }\end{array}$ & Brinjal, Okra, Bitter gourd, Chilli, Greens & Tomato, Brinjal, Beans & Brinjal, Chilli, Greens \\
\hline $\mathrm{T}_{4}(0.4$ acre $)$ & $\begin{array}{c}\text { Pine apple, Yam, Arrowroot, } \\
\text { Turmeric }\end{array}$ & \begin{tabular}{|c|} 
Brinjal, Okra, Bitter gourd, Ridge gourd, \\
Chilli, Greens, Coe pea
\end{tabular} & $\begin{array}{l}\text { Tomato, Brinjal, Cauliflower, } \\
\text { Onion, Greens }\end{array}$ & $\begin{array}{c}\text { Brinjal, Chilli, Pumpkin, } \\
\text { Greens }\end{array}$ \\
\hline $\mathrm{T}_{5}(0.5$ acre $)$ & $\begin{array}{c}\text { Pine apple, Yam, Arrowroot, } \\
\text { Turmeric, Ginger }\end{array}$ & \begin{tabular}{|c|} 
Brinjal, Okra, Bitter gourd, Ridge gourd, \\
Chilli, Greens, Coe pea
\end{tabular} & $\begin{array}{l}\text { Tomato, Brinjal, Cauliflower, } \\
\text { Onion, Greens }\end{array}$ & $\begin{array}{c}\text { Brinjal, Chilli, Pumpkin, } \\
\text { Greens }\end{array}$ \\
\hline $\mathrm{T}_{6}(0.6$ acre $)$ & $\begin{array}{c}\text { Pine apple, Yam, Arrowroot, } \\
\text { Turmeric, Ginger }\end{array}$ & $\begin{array}{l}\text { Brinjal, Okra, Bitter gourd, Ridge gourd, } \\
\text { Chilli, Greens, Cow pea }\end{array}$ & $\begin{array}{l}\text { Tomato, Brinjal, Cauliflower, } \\
\text { Onion, Greens } \\
\end{array}$ & $\begin{array}{c}\text { Brinjal, Chilli, Pumpkin, } \\
\text { Greens }\end{array}$ \\
\hline $\mathrm{T}_{7}(0.7$ acre $)$ & $\begin{array}{c}\text { Pine apple, Yam, Arrowroot, } \\
\text { Turmeric, Ginger }\end{array}$ & $\begin{array}{r}\text { Brinjal, Okra, Bitter } \\
\text { Chilli, Green }\end{array}$ & $\begin{array}{l}\text { Tomato, Brinjal, Cabbage, } \\
\text { Cauliflower, Onion, Greens }\end{array}$ & $\begin{array}{c}\text { Brinjal, Chilli, Pumpkin, } \\
\text { Greens }\end{array}$ \\
\hline $\mathrm{T}_{8}(0.8 \mathrm{acre})$ & $\begin{array}{c}\text { Pine apple, Yam, Arrowroot, } \\
\text { Turmeric, Ginger }\end{array}$ & $\begin{array}{l}\text { Brinjal, Okra, Bitter gourd, Ridge gourd, } \\
\text { Chilli, Greens, Cow pea }\end{array}$ & $\begin{array}{c}\text { Tomato, Brinjal, Cauliflower, } \\
\text { Greens }\end{array}$ & $\begin{array}{c}\text { Brinjal, Chilli, Pumpkin, } \\
\text { Greens }\end{array}$ \\
\hline $\mathrm{T}_{9}(0.9$ acre $)$ & $\begin{array}{c}\text { Pine apple, Yam, Arrowroot, } \\
\text { Turmeric, Ginger }\end{array}$ & $\begin{array}{l}\text { Brinjal, Okra, Bitter gourd, Ridge gourd, } \\
\text { Chilli, Greens, Cow pea } \\
\end{array}$ & $\begin{array}{l}\text { Tomato, Brinjal, Cauliflower, } \\
\text { Greens }\end{array}$ & $\begin{array}{c}\text { Brinjal, Chilli, Pumpkin, } \\
\text { Greens }\end{array}$ \\
\hline $\mathrm{T}_{10}(1.0$ acre $)$ & $\begin{array}{c}\text { Pine apple, Yam, Arrowroot, } \\
\text { Turmeric, Ginger }\end{array}$ & $\begin{array}{l}\text { Brinjal, Okra, Bitter gourd, Ridge gourd, } \\
\text { Chilli, Greens, Cow pea }\end{array}$ & $\begin{array}{c}\text { Tomato, Brinjal, Cauliflower, } \\
\text { Greens }\end{array}$ & $\begin{array}{c}\text { Brinjal, Chilli, Pumpkin, } \\
\text { Greens }\end{array}$ \\
\hline $\mathrm{T}_{11}(1.1$ acre $)$ & $\begin{array}{c}\text { Pine apple, Yam, Arrowroot, } \\
\text { Turmeric, Ginger }\end{array}$ & $\begin{array}{l}\text { Brinjal, Okra, Bitter gourd, Ridge gourd, } \\
\text { Chilli, Greens, Cow pea }\end{array}$ & $\begin{array}{c}\text { Tomato, Brinjal, Cauliflower, } \\
\text { Greens }\end{array}$ & $\begin{array}{c}\text { Brinjal, Chilli, Pumpkin, } \\
\text { Greens }\end{array}$ \\
\hline $\mathrm{T}_{12}(1.2$ acre $)$ & $\begin{array}{c}\text { Pine apple, Yam, Arrowroot, } \\
\text { Turmeric, Ginger }\end{array}$ & $\begin{array}{l}\text { Brinjal, Okra, Bitter gourd, Ridge gourd, } \\
\text { Chilli, Greens, Cow pea }\end{array}$ & $\begin{array}{c}\text { Tomato, Brinjal, Cauliflower, } \\
\text { Greens }\end{array}$ & $\begin{array}{c}\text { Brinjal, Chilli, Pumpkin, } \\
\text { Greens }\end{array}$ \\
\hline $\mathrm{T}_{13}(1.3$ acre $)$ & - & Paddy & - & - \\
\hline & - & & - & - \\
\hline $\mathrm{T}_{15}(1.5 \mathrm{acre})$ & - & Paddy & - & - \\
\hline
\end{tabular}

\subsection{Role played by coconut based agroforestry system}

The agro climatic condition of Puri district of Odisha is very suitable for growing coconut. In addition to this presence of more Hindu communities and large number of religious institution coconut finds a very sacred place in this part of Odisha since long time. Coconut based agroforestry system are playing multiple roles like various productive, protection and ameliorative, recreational and educational as well as developmental role. The common productive role is supply of various kinds of products like food, fodder, fuel, oil, shading material, broom material, timber etc. The common protective and ameliorative role includes acting as $\mathrm{CO}_{2}$ sink, restoring soil productivity, provides shade, moderating temperature, reducing wind speed, creating congenial micro climate, providing habitat for birds, acting as germplasm bank and helping in biodiversity conservation. It provides various recreational and educational roles such as aesthetic value, acting as learning ground for children and providing cultural and religious value. It also helps in generating employment in small holdings and employment as well as cash in large holdings. Many researchers also have highlighted such roles of homestead agroforestry systems. Rahman et al. (2013) ${ }^{[19]}$, Nair (2008) ${ }^{[17]}$, Ahmed et al. (2004) ${ }^{[3]}$, Senaid et al. (2004) [21]; Arunachalam et al. (2007) ${ }^{[5]}$ and Mohapatra et al. (2007) [16]. However in comparatively large holding which are more than 1.2acre where species diversity is less the role of the system is also comparatively less.

\subsection{Livestock in coconut based agroforestry system}

The livestock comprising animals and birds was found to be an integral part in most of the holdings size in coconut based agroforestry system in Puri district. The animal included cattle, buffalo and goat among which cattle was common in all size holding. The cattle number varied from 2 to 4 per holding with relatively higher number with higher holdings. Keeping of cattle is very common in rural areas of Odisha for milk and ploughing the land. Relatively more number is found where area is more to be ploughed. The buffalo were found in holding size of 0.3 acre to 1.3 acre numbering 2 to 3 per holding. In relatively small size as well as big size holding they were not found. This may be attributed to there no space for ploughing in smaller size as well as in large area where generally mechanized farming is practised. The goats were found in holding size of 0.1 acre to 0.9 acre. This indicates that small farmers having less land are preferring goat and the number varies 2-4 per holding. The total number of animal per holding varied from 4-9 with relatively more number between 0.4 and 1.0acre. This may be due to the fact that the middle size holding are preferring all three types of livestock. Integration of livestock in coconut based agroforestry system has also been reported by Sahoo, (2007) ${ }^{[20], ~ A l a m ~ a n d ~}$ Masom, (2005) ${ }^{[4]}$ and Nair and Sreedharan, (1986) ${ }^{[18]}$. With regards to birds poultry and ducks were found to be reared in different sizes of holding, 4-6 number of poultry bird was found up to the holding size 0.8 acre. This signifies that the small farmers having relatively small area are integrating the poultry bird to enhance their income. Ducks were found to be reared in 2 to 5 numbers in the holding size varying from 0.1 acre to 1.2 acre. This is because ponds are available in the backyards of Puri district and ducks are reared easily for egg and meat. Beyond 1.2acre holding sizes which are mostly paddy field ducks are not found because of absence of pond. The total numbers of birds in terms of poultry and duck varied from 2 to 10 in holding size of 0.1 acre to 1.2acre. Significantly higher numbers of birds were found in relatively smaller size holding because people try to enhance their income by integrating more number of birds in their small size holdings. Rearing of birds in coconut based agroforestry also been reported by Jhon and Nair, (1999) ${ }^{[10]}$, Ahmed and Hazarika, (2007) ${ }^{[1]}$ and Nair, (2008) ${ }^{[17]}$.

\subsection{Soil status under coconut based agroforestry}

The soil chemical status under different size of holdings was found to be significantly different from one another (Table 3). The organic carbon content was found maximum $(0.65 \%)$ in 0.1 acre holding and minimum $(0.46 \%)$ in 1.3 acre holding. It 
exhibited decreasing trend with increase of holding size. The $\mathrm{pH}$ of soil varied from 5.08 to 7.30 with gradual reduction from 0.1 acre size of holding to 1.5acre of size of holding. The available nitrogen content was significantly higher $(313.91 \mathrm{~kg} / \mathrm{ha})$ in 0.1 acre size and decrease upto $(258.77 \mathrm{~kg} / \mathrm{ha})$ with increase of holding size. Similar trend was obtained in case available phosphorous and potassium. The available $\mathrm{P}$ ranged from 26.07 to $39.48 \mathrm{~kg} / \mathrm{ha}$ while available $\mathrm{K}$ ranged from 129.57 to $161.01 \mathrm{~kg} / \mathrm{ha}$. The higher content of organic carbon, available $\mathrm{N}, \mathrm{P}$ and $\mathrm{K}$ was observed more in comparatively smaller holdings than larger holdings. This may be attributed to presence of more number perennial plant per unit area in small size unit holding than large size unit holding. Trees help addition organic carbon and release of nutrient to soil through their leaf litter, decay of roots and also fixation of nitrogen by some plant. The enhancement of nutrient status and organic carbon under the tree canopy has been reported by researcher like Meerabai et al. (2000) ${ }^{[14]}$. The $\mathrm{pH}$ also increase with increase of holding size which may perhaps due to the ability of perennial plant to convert the acid soil which is a common feature in soils of Odisha toward basicity because comparatively more perennial plant in unit area is present in smaller size holdings. The big holdings like $\mathrm{T}_{13}, \mathrm{~T}_{14}$ and $\mathrm{T}_{15}$ which possessed only coconut has perennial trees with paddy crop remained in acidic condition because of absence of perennial trees. Dr. Bhola (1995) ${ }^{[6]}$, Mishra, V.K and Bhola, N (1996) ${ }^{[15]}$ and Bhola, N and Mishra, V.K (1998) ${ }^{[7]}$ has also reported the increase of available N, P and K status in soil under the tree canopy in comparison to open area.

Table 3: Soil status in coconut based agroforestry system in Puri district of Odisha

\begin{tabular}{|c|c|c|c|c|c|}
\hline Treatment $($ Holding size) & $\mathbf{O C}(\%)$ & $\mathbf{p H}$ & Available N(Kg/ha) & Available P(Kg/ha) & Available K(Kg/ha) \\
\hline $\mathrm{T}_{1}(0.1$ acre $)$ & 0.65 & 7.43 & 313.91 & 39.48 & 161.01 \\
\hline $\mathrm{T}_{2}(0.2$ acre $)$ & 0.63 & 7.40 & 310.59 & 36.79 & 158.31 \\
\hline $\mathrm{T}_{3}(0.3$ acre $)$ & 0.62 & 7.30 & 307.45 & 35.42 & 154.36 \\
\hline $\mathrm{T}_{4}(0.4$ acre $)$ & 0.60 & 7.22 & 299.17 & 34.62 & 153.31 \\
\hline $\mathrm{T}_{5}(0.5$ acre $)$ & 0.59 & 7.14 & 296.73 & 34.78 & 149.02 \\
\hline $\mathrm{T}_{6}(0.6$ acre $)$ & 0.58 & 7.05 & 291.85 & 33.90 & 147.57 \\
\hline $\mathrm{T}_{7}(0.7$ acre $)$ & 0.57 & 6.78 & 286.36 & 33.72 & 146.42 \\
\hline $\mathrm{T}_{8}(0.8$ acre $)$ & 0.55 & 6.47 & 283.31 & 31.83 & 144.54 \\
\hline $\mathrm{T}_{9}(0.9$ acre $)$ & 0.53 & 6.36 & 278.09 & 31.03 & 140.51 \\
\hline $\mathrm{T}_{10}(1.0$ acre $)$ & 0.51 & 6.30 & 274.81 & 29.11 & 139.10 \\
\hline $\mathrm{T}_{11}(1.1$ acre $)$ & 0.50 & 6.20 & 270.02 & 28.61 & 137.47 \\
\hline $\mathrm{T}_{12}(1.2$ acre $)$ & 0.48 & 6.08 & 268.17 & 27.77 & 135.77 \\
\hline $\mathrm{T}_{13}(1.3$ acre $)$ & 0.46 & 5.90 & 265.57 & 27.03 & 133.10 \\
\hline $\mathrm{T}_{14}(1.4$ acre $)$ & 0.45 & 5.82 & 261.4 & 25.40 & 131.60 \\
\hline $\mathrm{T}_{15}(1.5$ acre $)$ & 0.45 & 5.80 & 258.77 & 24.07 & 129.57 \\
\hline $\mathrm{SEm}_{( \pm)}$ & 0.01 & 0.03 & 3.45 & 0.34 & 1.82 \\
\hline $\mathrm{CD}_{(0.05)}$ & 0.03 & 0.10 & 10.34 & 1.00 & 5.34 \\
\hline
\end{tabular}

\section{Conclusion}

The coconut based agroforestry system of Puri district of Odisha was observed to be rich in structure, function and soil chemical status upto holding size of $1.2 \mathrm{acre}$. The treatments upto 1.2acre size were found to be well composed of different types of plants such as tree species, fruit plants and seasonal crops along with coconut in four different layers. The livestock such as cattle, buffalo, goat, ducks and poultry are associated in most of the coconut based agroforestry systems. Coconut based agroforestry systems particularly upto 1.2acre size are providing not only financial benefits but various types of tangible and intangible benefits also to the households including food, fuel, timber, fodder, thatching and broom material, shade, good microclimate, habitat for birds, learning ground for children, aesthetic, cultural and religious values. Out of the 15 treatments, the coconut based agroforestry system of size 0.8 acre was found to be best among among the holding sizes studied with regard to structure, function and soil chemical status.

\section{References}

1. Ahmed AA, Hazarika DN. Agroforestry systems and practices prevailing in Assam. Agroforestry: systems and practices (eds. Puri, S. and Panwar, P.), 2007, 347-355.

2. Ahmed MFU, Rahman SML. Profile and use of multispecies tree crops in the homesteads of Gazipur District, Central Bangladesh. Journal of Sustainable Agriculture. 2004; 24(1):81-93.

3. Ahmed MFU, Rahman SML, Ahmed ASMM, Quebedeaux B. Agroforestry as it pertains to vegetable production in Bangladesh. Journal of Agronomy. 2004; 3(4):282-290.

4. Alam MS, Masum KM. Status of homestead biodiversity in the offshore island of Bangladesh. Research Journal of Agriculture and Biological Sciences. 2005; 1(3):246-253.

5. Arunachalam A, Arunachalam K, Tangjang S, Deb S. Homegarden systems in the humid tropics of NorthEastern India. Agroforestry: systems and practices (eds. Puri, S. and Panwar, P.), 2007, 403-414.

6. Bhola N. Studies on Relative Growth Performance and Soil Enrichment Potential of Some Nitrogen Fixing Trees. M.Sc. Thesis. Dr. YSP. University of Horticulture and Forestry, Solon, India, 1995.

7. Bhola N, Mishra VK. Influence of nitrogen fixing trees on the status of some micronutrient. 1998; 21(2):103-107.

8. Fernandes ECM, O'Kting'ati A, Maghembe J. The Chagga homegardens: A multistoried agroforestry cropping system on Mt. Kilimanjaro, Northern Tanzania. Agroforestry Systems. 1984; 2:73-86.

9. Isaac SR, Nair MA. Coconut gardens for agroforestry. Indian Coconut Journal. 2000; 31(3):14-16.

10. John J, Nair MA. Socio economic characteristics of homestead farming in south Kerala. Journal of Tropical Agriculture. 1999; 37(1/2):107-109.

11. John J, Nair MA. Differences with holding size in the composition of coconut based homesteads of Southern Kerala. Indian Coconut Journal. 2002; 33(5):7-10.

12. Maheswarappa HP, Hegde MR, Nanjappa HV. Arrowroot (Maranta arundinacea L.): a potential 
intercrop in coconut garden. Indian Coconut Journal. 2000; 31(3):20-21.

13. Manjunath BL, Balbatti MS, Dhandar DG. Intercropping in coconut for higher monetary returns. Developments in plantation crops research Proceedings of the 12th Symposium on Plantation Crops, Placrosym-XII, Kottayam, India, 1998, 199-202.

14. Meerabai M, Jayachandran BK, Asha KR, Geetha V. Boosting spice production under coconut gardens of Kerala: maximizing yield of turmeric with balanced fertilization. Better Crops International. 2000; 14(2):1012.

15. Mishra VK, Bhola N. Growth and soil amelioration potential of some nitrogen fixing trees. 1996; 1:16-20.

16. Mohapatra AK, Bhola N, Patnaik RK. Agroforestry systems and practices in Orissa. Agroforestry: systems and practices (eds. Puri, S. and Panwar, P.), 2007, 333346.

17. Nair PKR. Structure and function of Home gardens. An Introduction to Agroforestry (eds. Nair, P.K.R.), 2008, 91-94.

18. Nair MA, Sreedharan C. Agroforestry Farming Systems in the Homesteads of Kerala, Southern India. Indian Journal of Arecanut, Spices and Medicinal Plants. 1986; 5(1):23-30.

19. Rahman SA, Baldauf C, Mollee EM, Al-Pavel MA, AlMamun MA, Toy MM et al. Cultivated Plants in the Diversified Homegardens of Local Communities in Ganges Valley, Bangladesh. Science Journal of Agricultural Research and Management, 2013. Article ID sjarm-197, 6.

20. Sahoo UK. Agroforestry systems and practices prevailing in Mizoram. Agroforestry: systems and practices (eds. Puri, S. and Panwar, P.), 2007, 367-383.

21. Senaid M, Fikreta B, Lutvija K, Smiljka V. Growing fruit and vegetables on homestead. Radovi Poljoprivrednog Fakulteta Univerziteta u Sarajevu Works of the Faculty of Agriculture University of Sarajevo. 2004; 49(54(1)):97-101. 